\title{
Emotions for Artists: Intregrating two Textual Analysis Techniques in a Qualitative Perspective
}

\author{
Sônia Maria Guedes Gondim ${ }^{1}$ (C) \\ Pedro Fernando Bendassolli² (1) \\ Lilia Bittencourt Silva ${ }^{1}$ \\ Iago Andrade Carias ${ }^{1}$ (D) \\ Franciane Andrade de Morais ${ }^{1}$ \\ Liana Santos Alves Peixoto ${ }^{1}$
}

\begin{abstract}
This study aimed to show, by empirical evidence, that using different techniques of data analysis can contribute to the production of complementary knowledge about complex phenomena, such as emotions. The article discusses the results derived from using two textual analysis techniques and their articulation. Its main contribution is methodological, specifically in qualitative analysis supported by software. The study included 517 artists working in various artistic sectors, such as music and theater. ALCESTE and ATLAS.ti were used in the analysis. Results suggest convergences or complementarities between these two techniques. While ATLAS.ti allows for a dialogue between data and theory, through open coding, for better alignment between categorical theoretical system and data, ALCESTE organizes data in classes or categories, through calculations of word co-occurrence, which requires a theoretical frame to give them meaning.
\end{abstract}

Keywords: emotions, methodology, content analysis, computer programs, qualitative research

\section{Emoções para Artistas: Integrando duas Técnicas de Análise Textual na Perspectiva Qualitativa}

\begin{abstract}
Resumo: O objetivo deste estudo foi trazer evidências empíricas de que o uso de técnicas de análises de dados variadas pode contribuir para produzir conhecimento complementar sobre fenômenos complexos, como o das emoções. $\mathrm{O}$ artigo discute os resultados oriundos da utilização de duas técnicas de análise textual e sua articulação. Sua principal contribuição é metodológica, especificamente em análise qualitativa com suporte de softwares. Participaram do estudo 517 artistas que trabalhavam em diversos setores artísticos, como música e teatro. O ALCESTE e o ATLAS.ti foram usados nas análises. Os resultados sugerem convergências ou complementaridades entre essas duas técnicas. Enquanto o ATLAS.ti permite estabelecer um diálogo dos dados com a teoria, pela via da codificação aberta, para melhor alinhamento entre sistema teórico categorial e dados, o ALCESTE organiza a base dados em classes ou categorias, mediante cálculos de coocorrência de palavras, que necessitam de frame teórico para lhes dar sentido.
\end{abstract}

Palavras-chave: emoções, metodologia, análise de conteúdo, programas de computador, pesquisa qualitativa

\section{Emociones para Artistas: la Combinación de dos Técnicas de Análisis Textual de Enfoque Cualitativo}

\begin{abstract}
Resumen: El presente estudio propone aportar evidencias empíricas de que el uso de técnicas de análisis de datos variadas puede contribuir a la producción de conocimiento complementario sobre fenómenos complejos, como el de las emociones. El artículo discute los resultados del uso de dos técnicas de análisis textual y su articulación. Su principal contribución es metodológica, específicamente en el análisis cualitativo respaldado por softwares. En el estudio participaron 517 artistas que trabajaban en diversos sectores artísticos, como la música y el teatro. Para los análisis, se utilizaron el ALCESTE y ATLAS.ti. Los resultados apuntan convergencias o complementariedades entre estas dos técnicas. Mientras ATLAS.ti permite establecer un diálogo entre los datos y la teoría por medio de la codificación abierta para una mejor adecuación entre el sistema teórico categórico y los datos, ALCESTE organiza la base de datos en clases o categorías mediante cálculos de coocurrencia de palabras, que necesitan un frame teórico para darles significado.
\end{abstract}

Palabras clave: emoción, metodología, análisis de contenido, programas informáticos, investigación cualitativa

\footnotetext{
${ }^{1}$ Universidade Federal da Bahia, Salvador-BA, Brazil

${ }^{2}$ Universidade Federal do Rio Grande do Norte, Natal-RN, Brazil

Article derived from Lilia Bittencourt Silva master's thesis under the guidance of Sonia Gondim, defended in 2016, in the Graduate Program in Psychology of the Universidade Federal da Bahia. The researcher received funding from CAPES 2014-2016.

Correspondence address: Sonia Gondim. Universidade Federal da Bahia. Rua Rodrigo Argolo, 293, apto. 502, Salvador-BA, Brazil. CEP 41.940-220. E-mail: sggondim@gmail.com
}

This article discusses the possibilities of combining two textual analysis techniques applied to the same corpus. Although derived from empirical research, it served only as an illustration of comparative analysis. Its main contribution is methodological, specifically in qualitative analysis supported by software. The reason for using two techniques was to show evidence that quantitative and qualitative analysis of the same textual corpus can contribute 
to complementary knowledge production, especially in the case of complex phenomena, such as emotions, in an equally complex professional category, that of artists. The choice for artists' emotions is based on the premise that emotions constitute a nuclear part of these professionals work, acting as a motivational source and raw material upon which they create. It is also assumed that this theme would allow to comparatively test the interpreting power of two textual data analysis software commonly used in qualitative research.

The corpus regarding the artists' concepts of emotions pertain to a broader research that analyzed the relations between emotional work, engagement and workplace wellbeing (Silva, 2016). The target audience was mainly show artists, who performed in public exhibitions of a musical, imagery or body nature. Interest in public displays stems from the assumption that, in these situations, artists deal with unpredictable audience reactions (laughs, praise, criticism, booing, indifference), demanding management of their own emotions to ensure their performance and personal well-being. Although the article has a methodological focus, we consider it necessary to start with a brief contextualization on emotions, which allows for a contextualized understanding of the results interpretation obtained by the two analysis techniques.

The significance and complexity of emotions in human life are widely documented in literature, philosophy and various biological, social and human sciences (Damasio \& Carvalho, 2013; Davidson, Scherer, \& Goldsmith, 2003; Ekman, 2016). From Dixon's perspective (2012), for example, the distinction between passions and affections has roots in stoicism and Christianity, being one of the foundations of moral philosophy in the Middle Ages. These concepts traversed time and helped highlight the ambivalent nature of emotions: on the one hand, there are appetites and passions, impulsive emotional disorders that escape rational control; on the other, affections and desires, which, when fulfilling cognitive and social functions, contribute to the construction of lasting affective bonds, responsible for the survival of the species.

Emotions such as anger, joy, fear and disgust would meet evolutionary universal principles, having facial and body marks. Most complex emotions such as guilt, remorse, shame and pride, in turn, would serve as moral principles, foundations of life in society. Emotions thus fulfill diverse functions, merging biological, cultural, moral and contextual aspects (Barrett, 2017; Damasio \& Carvalho, 2013; Ekman, 2016; Gondim, 2015; Mulligan \& Scherer, 2012).

In seeking to deepen the understanding of what are emotions, Kleinginna and Kleinginna (1981) highlighted their different aspects, namely: (a) physiological activation; (b) internal subjective experience; (c) perception of bodily and mental changes; (d) reactive and expressive manifestation of internal affective states and external stimuli; (e) dysfunctional reactions that unbalance internal affective states that impacts mental health; and (f) integrated phenomenon, the result of the articulation of several affective states.

In recent decade, Izard (2010) advanced the discussion of how these aspects can be integrated and concludes that, despite controversies, emotions stem from the conjunction of physiological, cognitive and subjective components to provide organized responses to internal and external stimuli aiming at adaptation or adjustment. Other authors (Gondim, 2015) argue that emotions prepare the body and mind to act (adaptative dimension); help in the communication of internal states and the processes of interpersonal relationship (social dimension); and activate and guide behavior toward achieving objectives (motivational dimension).

In the specific context of the arts, besides acting as basic raw material of the artist's activity, emotions - or, more broadly, affective states (Mulligan \& Scherer, 2012), have a mobilizing role in the artist-public interaction, because viewers nourish the expectation, implicit or not, that the artist will be able to awaken affective reactions in them. Therefore, the artist's experience of artistic production is strongly centered on emotions and its dimensions, which makes them a topic of great scientific interest for psychology.

\section{Method}

\section{Participants}

Participated in this study 517 artists, of which $55.5 \%$ were male. Regarding activity, $35.7 \%$ were musicians; $31.1 \%$ theater actors; $13.1 \%$ dancers; $10.7 \%$ plastic or visual artists; and $5.2 \%$ circus artists. A small percentage (4.2\%) did not report their field of activity. The mean age was 39.4 years $(S D=13.5)$, whose variation was 18 to 77 years. About $37 \%$ had postgraduate education; $36.7 \%$ elementary or high school; and $26.3 \%$ graduates. The majority (58\%) had more than 10 years of work.

\section{Instruments}

Sociodemographic data were requested (gender, age, education, marital status, country of birth, artwork income, working time) in an electronic questionnaire, and included the following measures: Brotheridge and Lee's Emotional Labor Scale (2003) (ELE), adapted and validated in Brazil (ETE.-Br) by Silva (2016); Escala de Engajamento no Trabalho (EEGT - Work Engagement Scale) by Siqueira et al. (2014); and Escala de Bem-Estar no Trabalho (EBET Work Well-Being Scale) by Paschoal and Tamayo (2008). The instruments detailed description can be found in Silva (2016). For the purposes of this study, only the artists' answer to the questionnaire open question were used: How do you define emotion?

\section{Procedure}

Data collection. Participants were recruited by nonrandom criteria through indications from trade unions, universities, associations, institutions, schools, personal web pages, social networks and snowball sampling. The invitation to participate in the study was emailed to the 
artist's private address, along with an access link to the questionnaire. Access to the questionnaire was granted only after clicking the agreement button located below the Consent Form.

Data analysis. The corpus with the artists' responses was analyzed with the support of the software ATLAS.ti and ALCESTE. ATLAS.ti is used mainly, but not exclusively, in qualitative research to assist in data analysis and interpretation. The software was developed based on grounded theory, an inductive methodological approach of theoretical construction based on data (Ralph, Birks, \& Chapman, 2015).

In conjunction with this approach, it offers resources that subsidize the researcher's work corpus integration (Friese, 2014). Although grounded theory is inductive, it does not prevent the use, if deemed desirable by the researcher, of a previous system of categories to guide data interpretation. However, this aprioristic categorical system should be open to recoding if elements in the corpus point to new categories (open coding system). Such was the case with this study, in which new categories were created from elements present in the artists' responses. Moreover, authors adept of the grounded theory discuss whether the use of previous categories in data could unable the emergence of new information. Here, the use of preanalytical categories in ATLAS.ti was not to "force" data into a given analytical arrangement, but, as Strauss (1988) describes, allow axis creation based on the corpus from broad and structuring sensitive topics of the analyzed phenomenon.

ALCESTE is a textual analysis software essentially based on the chi-square statistics applied to the analysis of word co-occurrences, followed by ascending and descending hierarchical classification (Camargo, 2005). The starting point are the so-called Unidades de Contexto Iniciais (UCI - Starting Context Units). Here, such units correspond to the concepts of emotion given by the artists; next, these units are grouped into Unidades de Contexto Elementar (UCE Elementary Context Units). The latter represent the analyzed textual corpus in its entirety. The analysis procedure was based on the report generated by ALCESTE, where the identified classes, the representative words of each class and those that mark opposition to each of them, also missing words in each class, are shown, which delimitate borders between them. The software also makes use of matching factor analysis, allocating in axes and quadrants the classes found in each corpus, which allows for stablishing affinities and distances between them. The analyses were performed independently by two teams of researchers. Two of the authors were responsible for ALCESTE's analysis procedures, while two others constructed the previous category system and the corpus codification in ATLAS.ti. The two pairs did not communicate with each other during the respective analysis, integrated later by the team.

\section{Ethical Considerations}

The research was approved by the Research Ethics Committee of the Faculdade Adventista da Bahia, according to a standardized process via Plataforma Brasil, under registration CAAE no. 44484215.0.0000.0042.

\section{Results}

The results are first presented separately, guarding the specificity of each technique. This arises from the possibility, suggested in the objective, of a complementary investigation between both. The finds integration will be described in the next section.

\section{Results with ATLAS.ti}

Considering the procedure for constructing dialogue between categories a priori (deduction) and emerging categories from data (induction), five categories were elaborated for the corpus coding: (a) Nature, (b) State, (c) Activation source, (d) Functions, and (e) Effects of emotions. This categorization system sought to contemplate both the logical thread observed in the literature and the representation of the corpus under analysis.

The Nature category gathers conceptions referring to the type of emotions phenomenon, which can manifest themselves from discrete qualities that differentiate them (e.g. anger, joy, sadness) (Ekman, 2016), or as dimensions in a continuous, ranging between poles such as pleasure and displeasure, positive and negative, passive and active (Russell, 1980). The second category, State, cover references about the immaterial or material condition of emotions. In the first case, emotions are understood as states of mind, in the form of affections or cognitions (Phelps, 2006); in the second, their somatic indicators are highlighted (Damasio \& Carvalho, 2013).

Activation source is linked to the emotions origins, which may be internal, from the person themselves (from their thoughts, for example), or external - related to contextual aspects, such as other people and situations (Niedenthal \& Ric, 2017). The fourth category, Functions, groups conceptions that emphasize the objectives or purposes of emotions. Functions identified are (a) expressive (expression of internal states); (b) reactive (in face of external events); (c) instrumental (something that can be handled and controlled by the artist to enable his work); and (d) motivational (activator of human action) (Barrett, 2017; Barrett, Lewis, \& Haviland-Jones, 2016; Kleinginna \& Kleinginna, 1981).

The fifth and final category, Effects, brings together conceptions regarding the consequences of emotions. Their locus can be the person themselves, with positive or negative impacts on their internal states; or social relationships, when emotions are assumed to influence dynamics of personcontext interaction (Davidson et al., 2003). Figure 1 shows how this categorization scheme accommodated the open question responses data. Only the most prominent categories are highlighted in the following paragraph. 


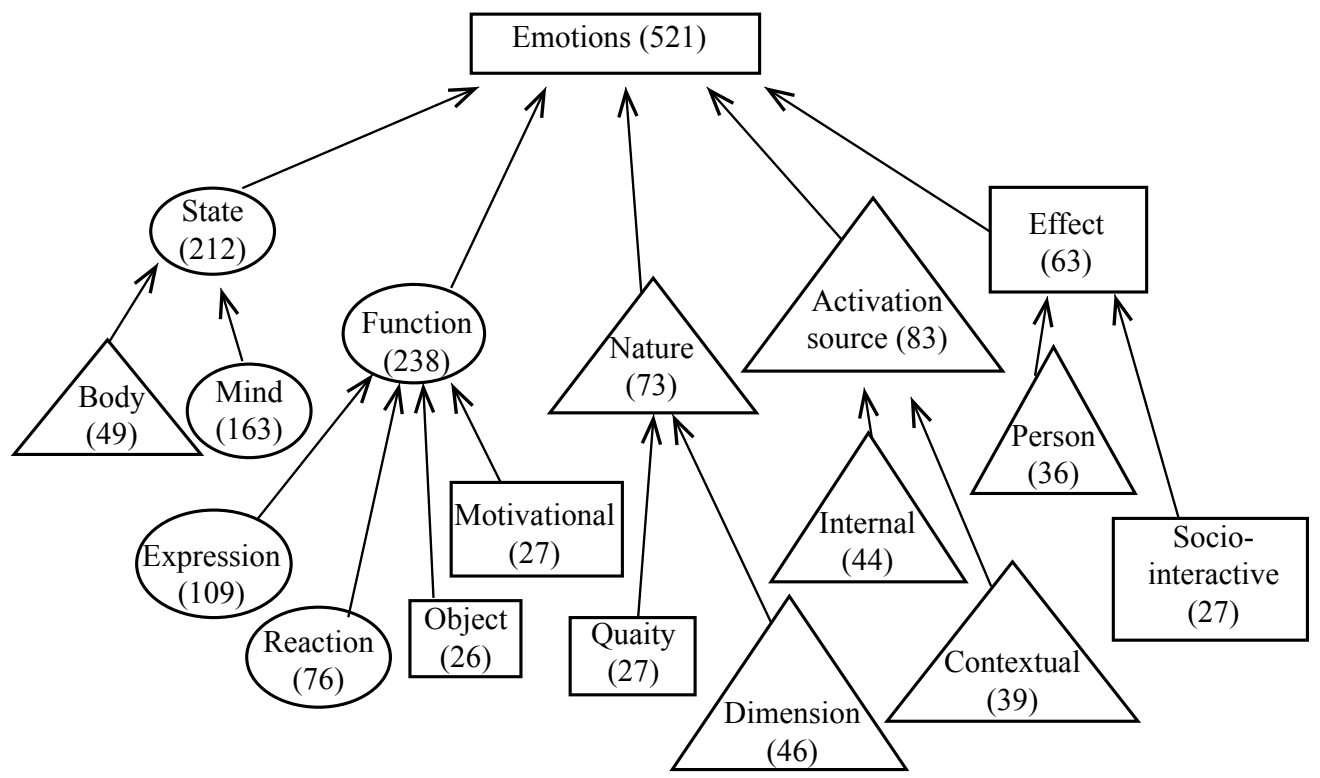

Low Intensity $\bigwedge$ Medium Intensity

High Intensity

Figure 1. Distribution of artists' conceptions of emotions in the five analytical categories created based on ATLAS.ti.

The prominent category in the artists' concepts of emotions is Functions $(n=238)$, with expression of internal states, with 109 citations, followed by reaction to external events, with 76 mentions as the most significant. The second is State $(n=212)$ : in the artists' understanding, emotions are characterized as a state of mind (immaterial), aspect mentioned 163 times. Then follows Activation source $(n=83)$, Nature $(n=73)$ and Effects $(n=63)$, respectively.
Some representative phrases of the various central nucleus that served as basis for the allocation and revision of categories were selected from the corpus (Figure 2) as examples. In the process of qualitative categorization, the items classification relies on semantic proximity with the category, where each item is classified based on identified themes that "correspond" to what defines the category. Furthermore, fragments of a single textual response can contemplate more than one analytical category.

- Set offeelings from internal subjective experiences (ideas, beliefs, dreams, imaginations, expectations, etc.) (c. activation source: internal) and external objectives (various degrees of interpersonal relationships, professional achievement) (c. activation source: external). [Musician]

- For me emotion is a sensory, bodily and spiritual process (c. state: body and mind), in which I respond to adverse situations, internal and external to my body (c. function: reaction), and organize them as feelings and behaviors (c. function: expression). By corporal I understand both the chemical, hormonal dimension (c. state: body). [Dancer]

- Chemical and psychophysiological response of the organism (c. state: body and mind) to an external stimulus (c. activation source: external), both physical or psychological, of the past as a memory (c. activation source: internal), of the present as a direct response to different situations and of the future as projection (c. function: reaction). [Musician]

- Emotion is a person's mood at any time (c. state: mind), that alters the entire functioning of the body and the mind (c. activation source: internal; c. effect: person). Elevating you to euphoria peaks or dipping you into deep sadness (c. effect: person; c. nature: dimension). [Musician]

- Emotion is the power to externalize intimate feelings (c. function: expression) that leave you in a state of joy, sadness, surprise, disappointment (c. nature: discreet qualities), finally, if someone looks at you, they know if you are well or not. [Visual and plastic arts]

Figure 2. Selection of sentences characterizing the central nucleus classified in each of the five central categories of the study from ATLAS.ti (*).

Observation: The phrases, extracted from 5 different artists, are presented by category (represented by "c.") and the specific facet mentioned (both highlighted in parentheses). 


\section{Results with ALCESTE}

The report generated by this software, which considers a corpus with 517 concepts of emotion (UCI), informs that $60 \%$ of the corpus was used, a percentage slightly lower than the $70 \%$ recommended by the literature (Camargo, 2005). Twenty co-occurrences defined each elementary context unity (UCE), and 554 UCE were found. Four classes were identified and distributed: Class 1 - 111 UCE, representing $34 \%$ of the analyzed corpus; class 2 - $64 \mathrm{UCE}, 19 \%$; class 3 -103 UCE, 31\%; and class 4 - 55 UCE, $16 \%$.
These classes were grouped into two axes. Axis 1 is characterized by responses that present emotion conceived as Form, emphasizing its expression (action and cognition), being composed of classes 1 (34\%) and $2(19 \%)$. In axis 2, definitions of emotion emphasize its Content, being considered positive (joy, harmony) or negative (sadness, fear), and qualified as a basic element, both of life and the artist's work. Thus, they end up playing a major role in their personal and professional achievement. This axis is composed of classes $3(31 \%)$ and $4(16 \%)$. The results are condensed in Table 1 , which gathers the most representative words of each class and absences, calculated based on the chi-square value.

Table 1

Representative and absent words in each class of the corpus analyzed, based on ALCESTE

\begin{tabular}{|c|c|c|c|c|c|c|c|}
\hline \multicolumn{4}{|c|}{$\begin{array}{c}\text { AXIS } 1 \\
53 \% \text { of significant UCE }\end{array}$} & \multicolumn{4}{|c|}{$\begin{array}{c}\text { AXIS } 2 \\
47 \% \text { of significant UCE } \\
\end{array}$} \\
\hline \multicolumn{2}{|c|}{$\begin{array}{c}\text { Class } 1 \\
34 \% \text { of significant UCE } \\
\end{array}$} & \multicolumn{2}{|c|}{$\begin{array}{c}\text { Class } 2 \\
19 \% \text { of significant UCE }\end{array}$} & \multicolumn{2}{|c|}{$\begin{array}{c}\text { Class } 3 \\
31 \% \text { of significant UCE } \\
\end{array}$} & \multicolumn{2}{|c|}{$\begin{array}{c}\text { Class } 4 \\
16 \% \text { of significant UCE }\end{array}$} \\
\hline Words & $\chi^{2}$ & Words & $\chi^{2}$ & Words & $\chi^{2}$ & Words & $\chi^{2}$ \\
\hline Human & 0.28 & Thought & 0.31 & Life & 0.32 & $\mathrm{Bad}$ & 0.37 \\
\hline Expression & 0.27 & Manifestation & 0.30 & To do & 0.28 & Moves & 0.32 \\
\hline Feelings & 0.25 & Action & 0.29 & Achievement & 0.26 & Feel & 0.31 \\
\hline Internal & 0.24 & Internal & 0.27 & Emotion & 0.25 & Feeling & 0.31 \\
\hline Reaction & 0.22 & Event & 0.27 & Knowledge & 0.23 & To be & 0.28 \\
\hline Perception & 0.22 & Relationship & 0.25 & Happy & 0.23 & Good & 0.27 \\
\hline External & 0.21 & World & 0.24 & Joy & 0.22 & Love & 0.24 \\
\hline- & - & External & 0.22 & Work & 0.22 & Good & 0.23 \\
\hline- & - & Mind & 0.22 & Art & 0.21 & Deep & 0.22 \\
\hline- & - & React & 0.22 & Able to & 0.21 & Perceived & 0.21 \\
\hline Absence & $\chi^{2}$ & Absence & $\chi^{2}$ & Absence & $\chi^{2}$ & Absence & $\chi^{2}$ \\
\hline Life & -0.21 & Expression & -0.18 & Body & -0.17 & Human & -0.12 \\
\hline To feel & -0.15 & Feeling & -0.16 & Expression & -0.14 & Person & -0.12 \\
\hline Joy & -0.14 & Can & -0.13 & Feelings & -0.14 & Life & -0.11 \\
\hline To do & -0.13 & To do & -0.12 & Way & -0.13 & Result & -0.09 \\
\hline Moment & -0.13 & Work & -0.12 & External & -0.13 & Experience & -0.09 \\
\hline- & - & Cheerful & -0.11 & Ours & -0.11 & External & -0.08 \\
\hline- & - & Human & -0.11 & Situation & -0.11 & Achievement & -0.08 \\
\hline
\end{tabular}

For didactic purposes, the concepts found in each class will be presented by each of the axes, starting with the most representative one, axis 1 (Form) - composed of class 1, where emotion is defined as a human expression of feelings; and class 2, in which emotion is seen as a mental and internal process, deriving from social and situational interaction, involving more cognitive aspects. In axis 2 (Content), the notions included in class 3 incorporate ideas of emotion as a central aspect of life associated with work and art, considering only its positive aspects. The notions present in class 4 , in turn, highlight the dubious and ambivalent nature of emotions, while also considering its negative aspects.

To illustrate how the representative words of each class are identified, here are some UCI (each definition given by the artist highlighted in quotation marks) and the UCE (words representative of the classes underlined). Of class 1: "emotion is the result of feelings, whether positive or negative, which can be felt internally or expressed by the various means of human expression, as speech and gestures"; "is the personal expression of a psychic and physical nature, of feelings we share with other people"; "is a complex body and psychic reaction, given to constant small or large oscillations, which can be stimulated and awakened by sensory and intellectual devices capable of transforming the actions and perception of the individual"; "an external expression of feelings." For class 2: "thought state that echoes through the body with distinct responses,(...) depending on the state of mind of the moment"; "everything in the world that moves me"; "something we feel and is directly or indirectly linked to the outside world and manifests itself mentally"; "the way 
a body manifests external factors the mind absorbs; it is like a stimulus, and must be expressed"; "everything that engenders an internal movement."

Class 3 (axis 2), is represented by the following definitions: "emotion is what makes us human; is what gives life taste and joy"; "emotion is what you feel when you're happy. It is the artist's main feeling when he accomplishes his work"; "is a job well done, which leads to viewer appreciation and good feedback"; "it is knowing how to live between joy and sadness, in harmony." Class 4: "it is something that grips us and alters our emotional state momentarily, whether good or bad"; "the feeling that motivates me to sing and play"; "a deep feeling, positive or negative, of compassion or anger"; "a feeling, a state of being."

Finally, the correspondence factor analysis identified proximity and distance zones between the classes. Classes 1 and 2 are closer, considering they conceive emotions as a form of expression and cognitive manifestations. These two classes are distant from classes 3 and 4, which highlight the qualitative facet of emotion (good or bad). While class 3 presents emotion as a central aspect of life, considering more its positive aspects, class 4 represents dubiousness, by adding the negative aspects of emotion more markedly. Thus, class 4 is further from classes 1 and 2 when compared to class 3 . Besides highlighting the proximity and distance zones between classes, the analysis allows identifying the most representative artistic categories of each class.

\section{Discussion}

Considering the aim of this article of discussing methodological issues in the analysis of qualitative data from a corpus derived from empirical research on emotions according to artists, this section focuses on the results generated using the two textual analysis techniques applied to the same corpus. Table 2 presents an integrated synthesis of the results obtained from ATLAS.ti and ALCESTE.

Table 2

Summary of the results obtained by each of the textual analysis techniques

\begin{tabular}{|c|c|c|c|c|}
\hline \multicolumn{5}{|c|}{ Artists' conceptions of emotions } \\
\hline \multicolumn{2}{|c|}{ Results with ATLAS.ti } & & \multicolumn{2}{|c|}{ Results with ALCESTE } \\
\hline Nature & $\begin{array}{l}\text { Aspect } \\
\text { DIMENSION }\end{array}$ & & $\begin{array}{c}\text { CLASS1 } \\
(34 \%)\end{array}$ & $\begin{array}{c}\text { Expression of feelings and } \\
\text { reactions }\end{array}$ \\
\hline Nature & MIND & Axis 1 & Theater & \\
\hline Activation source & $\begin{array}{l}\text { Body } \\
\text { INTERNAL } \\
\text { External }\end{array}$ & Form & $\begin{array}{l}\text { Class } 2 \\
(19 \%) \\
\text { Theater }\end{array}$ & $\begin{array}{l}\text { Mental and internal } \\
\text { elaboration of social } \\
\text { interctions }\end{array}$ \\
\hline Functions & $\begin{array}{l}\text { EXPRESSION } \\
\text { REACTION } \\
\text { Object }\end{array}$ & Axis 2 & $\begin{array}{l}\text { Class } 3 \\
(31 \%) \\
\text { Music }\end{array}$ & $\begin{array}{l}\text { Central aspect of human life } \\
\text { as well as in work and art }\end{array}$ \\
\hline Effects & $\begin{array}{l}\text { Motivation } \\
\text { PERSON } \\
\text { Socio-interactive }\end{array}$ & Content & $\begin{array}{c}\text { Class } 4 \\
(16 \%) \\
\text { Music }\end{array}$ & $\begin{array}{l}\text { Emotion dubiousness and } \\
\text { ambivalence as a part of life }\end{array}$ \\
\hline
\end{tabular}

The software ATLAS.ti, and others similar (NVivo, QDAMiner, for example), is essentially based on the same logic underlying a category analysis anchored in data, the support of which is based on grounded theory. Thus, two aspects are important. First is that the categorization system interacts with the data. Therefore, a category is an abstraction anchored in empirical data, reducing these in order to find a theoretical arrangement that can give meaning to the referred phenomenon. In this study, the categorical system sought to define different, although interrelated, ways of describing how artists define or conceive emotions. The second aspect is that they end up giving researchers prominence, because ultimately, they are the ones constructing categories from the in-depth reading of textual material or available literature, that may or may not be supplemented by memos or field records. All of these softwares can be put on the inductive-deductive axis of qualitative research.

ALCESTE also presents itself as a tool for qualitative research (as well as its most immediate "competitor",
Iramuteq), but works based on inductive logic: from a underlying logarithm, takes the "initiative" to propose to the researcher a corpus categorization from three main orientations: frequency (co-occurrence), importance (how much a particular textual unit is able to reduce data to its central elements) and context (based on the location of the classes representative words). Although the researcher has no interference in the processing performed by the software, he is the one who analyzes its "outputs", names the axes and classes to make interpretations consistent with his hypotheses or questions and, finally, establishes some relationship with the basis theory.

In the corpus of the artists' definitions, after the integrative and joint analysis of data generated with the help of both software, more convergence than divergence is observed - indicating that, despite the reduction logic adopted (inductive-deductive, or only inductive), the studied object central elements seem to be preserved. The 
evidenced convergence, however, does not function only as an expiration criterion, since the offered results complement each other in the understanding of the phenomenon. In other words, the results are not identical, but suggest convergence.

ATLAS.ti's results offer the possibility of analyzing the artists' definitions in line with a process of elaboration and upward theoretical debugging, rooted in constant data dialogue. ALCESTE's results, in turn, require the researcher to interpret a given result based on a specific algorithm, anchored in meta-theoretical conceptions about the functioning of language. In this study, both allow to visualize, from different starting points, concepts of emotions that highlight both the facet of appetites and passions (impulses) and of affections (desires and volition). This seems to confirm the importance of context when describing emotions (Davidson et al., 2003). The professional context refers mainly to that of musicians and theater artists, categories prevalent among the study participants used as illustration. These results can be explained by context variables, since artists who make public performances needs to deal with two sources of emotion activation to perform well: the first, resulting from the relationship established with their art for example, the music that is created and played, and the theatrical spectacle, which is elaborated and performed. The second is the relationship with the public, which reacts, positively or negatively (including indifference), to the artist's exhibition and interpretation. These contextual aspects also explain the convergence found in the corpus analysis made by the two software on the concept of emotion as an everyday life aspect and object of the artist's work, mainly evidenced by those who are dedicated to music.

In ATLAS.ti results, elements of this class are mentioned as one of the functions of emotions, that of object, complementing the functions of expression and reaction (class 3 of ALCESTE). Moreover, although they belong to different axes, classes 1 and 3 are close, converging with ATLAS.ti's results - which highlight the importance of functions of emotions in the artists' opinions. Finally, the understanding of emotions as something belonging to the intangible (psychological), with an internal activation source, portrayed in ATLAS.ti results, are represented in class 2 of ALCESTE, which brings together two facets, mental/internal (cognitive process) and external process (social interaction).

The less frequent categories, however, bring additional understandings about the artists' concepts of emotions. With ATLAS.ti, this occurred with the Emotion effect category, suggesting that artists consider such effects more related to the person itself than to interpersonal relationship. This result can be explained by the artist greater need to resort to introspection, since emotions are an important part of the "material" on which art is produced (Macêdo, 2010).

ALCESTE's class 4, although not pointing to a direct relationship with the previous ATLAS.ti result, was also considered the least representative of the corpus. This class highlights emotion ambivalence as part of life. As with ATLAS. ti, here also the result can be interpreted considering that artists, by the very nature of their activity, is sometimes led to live the dubiousness of emotions, for example, when preparing to play a complex character or when composing or interpreting a song.

The results from both techniques do not indicate direct divergences. Precisely the opposite, convergences and complementarities, because each technique offers its contribution to understand the corpus from a distinct starting point. In ATLAS.ti, although the categorical construction starting point was the literature on the subject, an open coding system was used, which allowed the constant comparison with the data, leading to the refinement of the theory that inspired the construction of a new category. This shows that the researcher has a prominent role in simplifying data. In ALCESTE, the researcher's role is to give theoretical meaning to an output generated by the software itself, which makes use of a calculation basis, not always the researcher's domain. In terms of methodological debate, however, these two perspectives have, over time, provoked intense discussions.

On the one hand, some authors are more aligned with a "purist" tradition of the grounded theory - such as Glaser (2002), one of its initial proponents. On the other hand, there is a chain of authors who question this form of radical "suspension", so to speak, sometimes calling it naïve (Dey, 1999). In a review study on the issue, Kelle (2005) states that the essence of the debate lies, in philosophy of science, on different concepts of "theory". One way around the issue of induction and deduction role in the construction of theory is to merge both - thus postponing their confrontation (Guest, MacQueen, \& Namey, 2012). A more recent proposed solution has been to change some terms of this debate, more directly discussing the relationship between theory and phenomena, including other forms of "access" and "construction" - such as abductive reasoning (Bendassolli, 2013).

Because of the methodological focus of this article, our conclusions refer to the use of different textual analysis software to analyze the same corpus. The first conclusion is the evidence of convergent validity, resulting from the similarity in the results obtained in the two data analyses. Although convergent validity refers to a construct validity test criterion, it is possible to use this concept as an analogy to the fact that two methodological techniques of data analysis have identified common central nucleus of meaning, even if named in different ways.

Second, is that the understanding of a complex phenomenon such as emotions was expanded by using the two software, because of complementarity in explaining the data. In recent years, we have witnessed a debate on the use of multiple methods to expand the explanatory power of phenomena. Despite those who defend the independence of the method (Cherryholmes, 1992), reaffirming that its choice relates to pragmatic criteria and functionality in the phenomenon approach, we align with those who advocate to "friction" different methods and techniques (Greene \& Caracelli, 1997), in which multiple approaches impose desirable challenges to achieve an integrative, although nonlinear vision, compelling researchers to a mental flexibility relativizing immeasurable epistemological paradigms.

The third conclusion is a complement to the second. The two software were useful to illustrate the importance of 
researchers adopting triangulation strategies. Following Denzin (1970) perspective, triangulation refers to combining methods to overcome "personal" biases from single methodological choices. Triangulation can occur on three levels: theories (various theories to analyze the same phenomenon), methods (varied methods and techniques), and researchers (several researchers analyzing the same phenomenon or data). This study highlights the triangulation of methods of data analysis.

In summary, perhaps the main contribution of this article is emphasizing how treatment of complex phenomena in qualitative research can benefit from the combination of two data analysis techniques. An open categorical system, such as ATLAS.ti, provides researchers with autonomy in choosing categories according to their theoretical affinities, especially when performing data analysis alone. It cannot be ensured, however, that other researchers analyzing the same corpus would reach the same results. The development of intraresearch consistency strategies (e.g. the Kappa index) aims to deal with this problem. ALCESTE, on the contrary, allows for a corpus standardized processing, based on an aprioristic logic, but cannot dispense with shared information to give meaning to emerging categories. This is a complex theoretical elaboration process. Although ALCESTE was created to operationalize social representations studies, it allows a wide application and offers great potential for theoretical construction.

Three limitations can be identified. First, the use of $60 \%$ of the textual corpus for analysis purposes in ALCESTE, when the literature recommends $70 \%$. Second, the analytical triangulation strategy management when the researcher uses more than one open question. In the empirical study analyzed, the artists answered only one, resulting in a homogeneous corpus. It is unclear how to proceed in case of different objects (or facets) of the same content. The third limitation is linked to the depth level of the artists' interpretations of emotions, used here only as illustration. However, the results suggest variations in the characterization of emotions related to the type of artistic activity, which was not explored.

Finally, it is worth mentioning that the effort to integrate textual data analysis techniques was to bring inputs to methodological discussions in favor of the improvement of qualitative research. One of the major challenges of this type of research is to meet the validity criteria and reliability required by scientific production. Methodological aspects addressed in this article are expected to help in critical reflection on the paths of qualitative research in Psychology.

\section{References}

Barrett, L. F. (2017). How emotions are made: The secret life of the brain. Boston, MA: Mifflin Harcourt.

Barrett, L. F., Lewis, M., \& Haviland-Jones, J. M. (2016). Handbook of emotions (4th ed.). New York, NY: Guilford.

Bendassolli, P. F. (2013). Theory building in qualitative research. Forum Qualitative Sozialforschung, 14(1), 1-20. doi:10.17169/fqs-14.1.1851
Brotheridge, C. M., \& Lee, R. T. (2003). Development and validation of the Emotional Labor Scale. Journal of Occupational and Organizational Psychology, 76(3), 365-379. http://dx.doi.org/10.1348/096317903769647229

Camargo, B. V. (2005). ALCESTE: Um programa informático de análise quantitativa de dados textuais [ALCESTE: A software to qualitative analisys of textual data]. In A. S. P. Moreira, B. V. Camargo, J. C. Jesuíno, \& S. M. Nóbrega (Orgs.), Perspectivas teórico-metodológicas em representações sociais (pp. 511-539). João Pessoa, PB: UFPB/Editora Universitária.

Cherryholmes, C. H. (1992). Notes on pragmatism and scientific realism. Educational Researcher, 21(6), 13-17. doi:10.3102/0013189X021006013

Damasio, A., \& Carvalho, G. B. (2013). The nature of feelings: Evolutionary and neurobiological origins. Nature Reviews. Neuroscience, 14(2), 143-152. doi:10.1038/nrn3403

Davidson, R. J., Scherer, K. R., \& Goldsmith, H. H. (2003). Handbook of affective sciences. New York, NY: Oxford University Press.

Denzin, N. K. (1970). The research act: A theoretical introduction to sociological methods. Chicago, IL: Aldine.

Dey, I. (1999). Grounding Grounded Theory: Guidelines for qualitative inquiry. Bingley, United Kingdom: Emerald.

Dixon, T. (2012). Emotion: The history of a keyword in crisis. Emotion Review, 4(4), 338-344. doi:10.1177/1754073912445814

Ekman, P. (2016). What scientists who study emotion agreed about. Perspectives on Psychological Science, 11(1), 31-34. doi:10.1177/1745691615596992

Friese, S. (2014). Qualitative data analysis with ATLAS.ti (2nd ed.). London, United Kingdom: Sage.

Glaser, B. G. (2002). Constructivist Grounded Theory? Forum Qualitative Sozialforschung, 3(3), 1-14. doi:10.17169/fqs-3.3.825

Gondim, S. M. G. (2015). Emoções [Emotions]. In P. F. Bendassolli \& J. E. Borges-Andrade (Orgs.), Dicionário de psicologia, organizações e trabalho [Dictionary of psychology, organization, and work] (pp. 311-324). São Paulo, SP: Casa do Psicólogo-Pearson.

Greene, J. C., \& Caracelli, V. J. (1997). Advances in mixedmethods evaluation: The challenges and benefits of integrating diverse paradigms. San Francisco, CA: Jossey-Bass.

Guest, G., MacQueen, K. M., \& Namey, E. E. (2012). Applied thematic analysis. Thousand Oaks, CA: Sage.

Izard, C. E. (2010). The many meanings/aspects of emotion: Definitions, functions, activation, and regulation. Emotion Review, 2(4), 363-370. doi:10.1177/1754073910374661 
Kelle, U. (2005). Emergence vs. Forcing of empirical data? A crucial problem of Grounded Theory reconsidered. Forum Qualitative Sozialforschung, 6(2), 1-22. doi:10.17169/fqs-6.2.467

Mulligan, K., \& Scherer, K. R. (2012). Toward a working definition of emotion. Emotion Review, 4(4), 345-357. doi: $10.1177 / 1754073912445818$

Niedenthal, P. M., \& Ric, F. (2017). Psychology of emotion (2nd ed.). New York, NY: Routledge.

Paschoal, T., \& Tamayo, A. (2008). Construção e validação da Escala de bem-estar no trabalho [Construction and validation of the Well-being at Work Scale]. Avaliação Psicológica [Psychological Assessment], 7(1), 11-22. Retrieve from http://pepsic. bvsalud.org/scielo.php?script=sci_arttext\&pid=S167704712008000100004\&lng=pt\&tlng=pt.

Phelps, E. A. (2006). Emotion and cognition: Insights from studies of the human amygdala. Annual Review of Psychology, 57, 37-53. doi:10.1146/annurev. psych.56.091103.070234

Ralph, N., Birks, M., \& Chapman, Y. (2015). The methodological dynamism of Grounded Theory. International Journal of Qualitative Methods, 14(4), 1-6. doi:10.1177/1609406915611576

Russell, J. A. (1980). A circumplex model of affect. Journal of Personality and Social Psychology, 39(6), 1161-1178. doi:10.1037/h0077714

Siqueira, M. M. M., Martins, M. C. F. M., Orengo, V., \& Souza, W. S. (2014). Engajamento no trabalho [Engagement at work] In M. M. M. Siqueira, Novas medidas do comportamento organizacional: ferramentas de diagnóstico e de gestão (pp. 147-156) [New measures of organizational behavior: diagnostic and management tools]. Porto Alegre: Artmed.

Silva, L. B. (2016). Trabalho emocional, engajamento no trabalho e bem-estar no trabalho de artistas de espetáculo [Emotional work, work engagement, and well-being in the work of entertainment artists] (Master's thesis). Retrieved from https://pospsi.ufba.br/sites/pospsi.ufba. br/files/lilia_bittencourt.pdf

Strauss, A. L. (1988). Discovering new theory from previous theory. In Qualitative analysis for social scientists (pp. 306-311). New York, NY: Cambridge University Press.
Sônia Maria Guedes Gondim is a professor of the Instituto de Psicologia at the Universidade Federal da Bahia, SalvadorBA, Brazil.

Pedro Fernando Bendassolli is a professor of the Universidade Federal do Rio Grande do Norte, Natal-RN, Brazil.

Lilia Bittencourt Silva é Ph.D. candidate of the Instituto de Psicologia at the Universidade Federal da Bahia, SalvadorBA, Brazil.

Iago Andrade Carias is a master's degree candidate of the Instituto de Psicologia at the Universidade Federal da Bahia, Salvador-BA,Brazil.

Franciane Andrade de Morais is a Ph.D. of the Instituto de Psicologia at the Universidade Federal da Bahia, SalvadorBA, Brazil.

Liana Santos Alves Peixoto is a Ph.D. candidate of the Insituto de Psicologia at the Universidade Federal da Bahia, Salvador-BA, Brazil.

\section{Authors' Contribution:}

All authors made substantial contributions to the conception and design of this study, to data analysis and interpretation, and to the manuscript revision and approval of the final version. All the authors assume public responsibility for content of the manuscript.

Received: Mar. 14, 2017

1st Revision: Jan. 31, 2018

2nd Revision: May. 14, 2018

Approved: Jul. 24, 2018

How to cite this article:

Gondim, S. M. G., Bendassolli, P. F., Silva, L. B., Carias, I. A., Morais, F. A., \& Peixoto, L. S. A. (2020). Emotions for artists: Integrating two textual analysis techniques in a qualitative perspective. Paidéia (Ribeirão Preto), 30, e3009. doi:http://dx.doi.org/10.1590/1982-4327e3009 